\title{
Protective and Curative Potentials of Sida corymbosa Extract Against Antioxidant Depletion in Rats Administered Carbon Tetrachloride
}

\author{
Charles Chijioke Dike ${ }^{1, *}$, Francis Chukwuemeka Ezeonu ${ }^{2}$, Chinenye Enoch Oguazu², \\ Emmanuel Nonso Ezeokafor ${ }^{3}$, Hugh Clifford Chima Maduka', Aloysius Ngozika Okpogba ${ }^{1}$, \\ Akpoghene Eyeghre Onoriode ${ }^{3}$, Sunday Jacob Asebioyo ${ }^{4}$, Emilia Chika Nwankwo ${ }^{1}$, \\ Ebelechukwu Nwaoma Ihekwoaba ${ }^{5}$, Aronu Cecilia Nkechi ${ }^{5}$

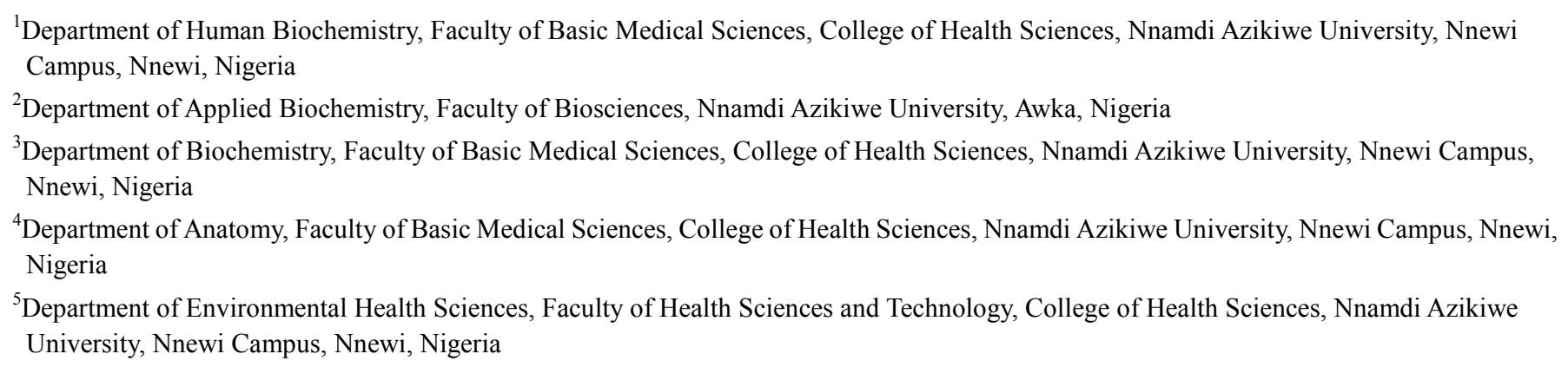

Email address:

cc.dike@unizik.edu.ng (C. C. Dike), fc.ezeonu@unizik.edu.ng (F. C. Ezeonu), ce.oguazu@unizik.edu.ng (C. E. Oguazu), emmaezeokafor@gmail.com (E. N. Ezeokafor), hcc.maduka@unizik.edu.ng (H. C. C. Maduka), okpogba4real@yahoo.com (A. N. Okpogba), eyeghreo@yahoo.com (A. E. Onoriode), sundayjacob888@gmail.com (S. J. Asebioyo), queen.emilia@yahoo.com (E. C. Nwankwo), ebykwas@yahoo.com (E. N. Ihekwoaba), ceciliankemaronu@gmail.com (A. C. Nkechi)

${ }^{*}$ Corresponding author

\section{To cite this article:}

Charles Chijioke Dike, Francis Chukwuemeka Ezeonu, Chinenye Enoch Oguazu, Emmanuel Nonso Ezeokafor, Hugh Clifford Chima Maduka, Aloysius Ngozika Okpogba, Akpoghene Eyeghre Onoriode, Sunday Jacob Asebioyo, Emilia Chika Nwankwo, Ebelechukwu Nwaoma Ihekwoaba, Aronu Cecilia Nkechi. Protective and Curative Potentials of Sida corymbosa Extract Against Antioxidant Depletion in Rats Administered Carbon Tetrachloride. American Journal of Biomedical and Life Sciences. Vol. 9, No. 2, 2021, pp. 97-110. doi: 10.11648/j.ajbls.20210902.11

Received: May 27, 2020; Accepted: June 15, 2020; Published: March 4, 2021

\begin{abstract}
Sida corymbosa plant is one of medicinal plants used in many parts of Africa, including Nigeria for the treatment of human diseases. The purpose of this work was to investigate the antioxidant effects of Sida corymbosa ethanolic leaf extract on rats administered carbon tetrachloride $\left(\mathrm{CCl}_{4}\right)$. One hundred and sixty male-rats between $170-180 \mathrm{~g}$ were used. They were grouped into 8 major groups (groups $\mathrm{A}-\mathrm{H})$ and 4 subgroups $\left(\mathrm{A}_{1}-\mathrm{H}_{4}\right)$ in each group making it 32 subgroups of 5 rats each. The major groups comprise A (positive control- normal rats giving feed and water only and left for 7-28 d), B (negative control-those administered $\mathrm{CCl}_{4}$ only at $0.4 \mathrm{ml} / \mathrm{kgbw}$ and left for 7-28 d), C-H (treatment groups-those administered extract before and after $\mathrm{CCl}_{4}$ administration at 5,000, 3,000 and 1,000 mg/kgbw for 7-28 d). Antioxidant assays were determined using UV-VIS spectrophotometer (model 752g, China). Results of serum antioxidant assays done revealed that levels of serum reduced glutathione (GSH), glutathione peroxidase (GPx), catalase (CAT), supraoxide dismutase (SOD) and total antioxidant capacity (TAC) increased significantly $(\mathrm{P}<0.05)$ in the treatment groups from 7-28 d, when compared with the negative control. Oxidative assay carried out showed that serum malondialdehyde (MDA) levels were significantly lower $(\mathrm{P}<0.05)$ in treatment groups than in negative control groups. These may be suggesting that the extract may have improved the antioxidant levels of the rats. Sida corymbosa ethanolic leaf extract may, therefore, have positive effects on antioxidant status of rats administered $\mathrm{CCl}_{4}$.
\end{abstract}

Keywords: Sida Species, Antioxidant Results in Rats, Oxidative Stress 


\section{Introduction}

Background of study

Carbon tetrachloride $\left(\mathrm{CCl}_{4}\right)$ is one of the xenobiotic which when exposed to, can cause damage to the liver, kidney and some other organs in the body. It does these by inducing stress to these organs. Carbon tetrachloride has been used as a model chemical by many researchers in inducing oxidative stress in experimental animals especially Albino rats and mice [1-2]. Most xenobiotic induce oxidative DNA damages in cells of the body. Hepatotoxicity effects of $\mathrm{CCl}_{4}$ on male-Albino rats have been reported by Dike et al., [3].

Oxidative stress is increasing alarmingly globally due to increased exposure to xenobiotic substances, thereby given rise to a lot of diseases such as liver, kidney, cardiac and other age related diseases. Free radicals are basic biological stages which form part of breathing and metabolic processes [4]. Ultra violet radiations, consumption of had drugs, substance abuse or drug abuse had been known to cause the production of free radical [4], which generates reactive species. These species include reactive oxygen species (ROS) and reactive nitrogen species (RNS). Free radicals have been reported to be produced inside biological cells from many pathways ${ }^{5}$. Reactive species play vital functions in apoptosis, expression of gene, ion transport and signalling of cell. Excess ROS and RNS do cause damages biomolecules such as proteins, DNA telomeres, DNA and lipid [6]. Reactive oxygen species and reactive nitrogen species have been reported by Obi et al., [7], to be produced inside the body.

The use of malondialdehyde (MDA) serves as an important diagnosing tool for oxidative stress since MDA is a product of lipid peroxidation. Antioxidant molecules have been widely regarded as molecules which play important roles in reducing or preventing oxidative stress in the body. There is increased interest globally on the use of antioxidants both natural and synthetic ones [8]. This may be as a result of increased in oxidative stress-related diseases worldwide. A lot of oxidation process has been reported to be retarded by the use of synthetic antioxidants [8]. The human body has inbuilt mechanisms to protect tissues from reactive species-induced damages in the cell. Enzymes such as catalase (CAT), supraoxide dismutase (SOD), glutathione peroxidase (GPx) and non-enzyme molecules such as glutathione together form antioxidant defence system. The level of antioxidant defence system in the body had been known to vary from individual to individual, is dependent on age. Antioxidants such as GSH, GPx, catalase and SOD have been reported by Maher et al., [9], to have decreased in male rats administered $\mathrm{CCl}_{4}$ only and increased in male rats administered $\mathrm{CCl}_{4}$ and treated with Ficus carica leaf extract.

Medicinal plants serves as basis for the source of knowledge of orthodox medical practice ${ }^{10}$. It reflects the confirmation of a lot of traditional claims with regards to the quality of natural products of plants in health care delivery [ 10 , 11]. Africans, both educated and non-educated people have been using traditional remedies for a long time successfully
[12]. A lot of orthodox drugs have been isolated from plants. Plants with high antioxidant potentials may be used as traditional medicines for aging and chronic disease prevention ${ }^{1}$. Human beings have been using plants for a long time, even before the inception of civilization for the treatment of diseases. He obtained the information about the medicinal uses of plants through guess work and passed the information from one generation to the other without scientific validation. Most traditional medical practitioners use medicinal plants in the treatment of diseases without following the standard guidelines in determining the acute toxicity of plants [13, 14], thereby creating doubts on the health-safety of the drugs.

Sida species are among the ethnomedicinally important genius of plants [16], which belong to the family of plants called malvaceae $[17,18]$. There are over 200 species of sida. Sida species have been reported to contain phytochemicals such as phenolics, antioxidants like kaempferol, epicatechin, phenol, anthocyanin and rutin, which have the potentials to regenerate liver cells [3]. Dike et al., [3] reported that Sida corymbosa leaf and root extracts contain potassium, zinc, sodium, iron, magnesium, copper, manganese, cobalt, calcium, sulphate, chloride and phosphate, which are among the mineral elements required by animals for healthy growth. Some of these mineral elements are involved in the maintenance of acid-base balance in the body [19]. Sida species have been used in many traditional medicines in the treatment of cardiac and age related illness [20]. Mahesh et al., [20] reported that 30 species of sida were found in African countries, 35 in Austrialia, \pm 110 in North Central and South Africa. Differences in pharmacological activities of Sida species may occur, since the chemical profiles vary.

Sida corymbosa plant is an erect, branched, small and perennial herb which is found in most parts of Eastern, Western and Northern Nigeria, growing alongside of roads, streets and refuses heaps as common weeds [1-3]. The people of South East of Nigeria call it Udonwatakaike, Udoike, Acharaike or Udontike, depending on the part of South East; the people of South Western part of Nigeria call it Sepotu while the people of Northern part of Nigeria call it Lamaruda. It is also found in many other parts of world like China, France, India, etc. Different parts of this plant such as leaves, seeds, bark and flowers are used in traditional medicine for the treatment of many diseases [21]. It is used in many parts of Asian countries like Philippine, for the treatment and management of diseases such as asthma, stomach pains, coughs, tooth problems and fever. It survives all kinds of weathers and is propagated through all modes of propagations (stem, roots and seeds). Sida corymbosa have been reported by Lucy et al., [22], to have antiulcer activities in rats.

Literature abound on the haemostatic, antibleeding, antiulcer and antirust properties of $S$. corymbosa leaf extracts but there is scanty information on the antioxidant potentials of $S$. corymbosa extracts. There have been claims by some traditional medical practitioners on the usefulness of Sida corymbosa leaves in the improvement and management of antioxidant status in human without any scientific validation. 
The purpose of this work was therefore to close this gap by investigating the effects of Sida corymbosa extracts on Albino-male rats before and after administering carbon tetrachloride (Protective and curative treatment).

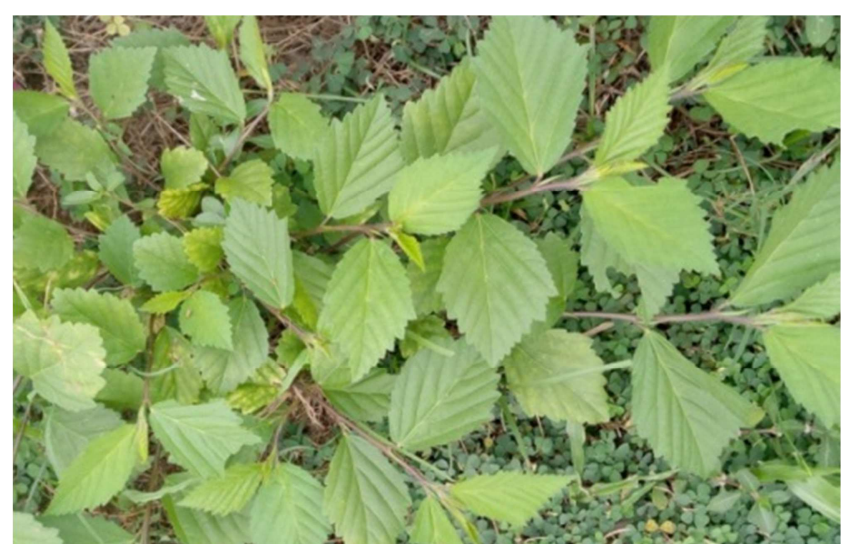

Figure 1. Photograph of Sida corymbosa plant.

\section{Materials and Methods}

\subsection{Materials Used}

All chemicals that were used in this work were of analytical grade and were obtained from Sigma Aldrich, Germany, through their sales representative in Ikeja, Lagos State, Nigeria. These include; ascorbic acid, concentrated tetraoxosulphate six acid $\left(\mathrm{H}_{2} \mathrm{SO}_{4}\right)$, ammonium molybdate $\left([\mathrm{NH} 4]_{6} \mathrm{MO}_{7} \mathrm{O}_{24}\right)$, sodium phosphate $\left(\mathrm{NaPO}_{4}\right)$, absolute ethanol (98.5\%), absolute methanol (98.5\%), 2,2'-Diphenyl-1-picrylhydraziyl (DPPH), ferrous chloride, ferrozine, 2,4,6-Tris (1-pyridyl)-5-triazine (TPTZ), sodium acetate buffer ( $\mathrm{pH} 3.6$ ), hydrogen peroxide, sodium salicylate, trolex standard, quercitin, ethylene diamine tetracetic acid (EDTA) and carbonate buffer. Others were; epinephrine, trichloroacetic acid, thiobarbituric acid, phosphate buffer, dithiobis-2-nitrobenzoic acid (DTNB) and reduced glutathione (GSH) standard. Distilled water used were obtained from Human Biochemistry Laboratory, Faculty of Basic Medical Sciences, College of Health Sciences, Nnamdi Azikiwe University, Nnewi Campus. Albino-male rats which were used in this study were obtained from the Animal Facility Unit of Faculty of Basic Medical Sciences, College of Health Sciences, Nnamdi Azikiwe University, Nnewi Campus, Anambra State, Nigeria.

Animal feeds used was vital growers, a commercial pellet diet gotten from Gland Cereals Ltd., Plateau State, Nigeria, via her sales representative at Nnewi, in Nnewi-North Local Government Area, Anambra State, Nigeria.

Sida corymbosa plant samples were obtained from Okofia-Otolo, in Nnewi-North Local Government Area, Anambra State, Nigeria. It was identified and authenticated by Prof. J. C. Okafor, a taxonomist at Enugu State University of Science and Technology (ESUT), Enugu State, Nigeria. It was further confirmed with the issuance of the herbarium No: NAU/ 75/G, at the Department of Botany, Nnamdi Azikiwe University-Awka, Anambra State, Nigeria.

\subsection{Methods}

\subsubsection{Preparation of Plant Materials}

Plant leaves and roots were prepared according to the method described by Sundaraganapathy et al., [18]. The leaves and roots of the plant were washed with distilled water; air-dried at room temperature and powdered using a blender. The ethanol extracts were obtained by soaking $25 \mathrm{~g}$ of each of dried leaves and roots respectively in round bottom flasks containing $200 \mathrm{ml}$ of absolute ethanol (98.5\%) for forty-eight hours with occasional shaking. The ethanolic extracts were filtered through $40 \mathrm{~mm}$ Whatman filter paper and evaporated using a rotary evaporator (Model: TT22, USA) at $65^{\circ} \mathrm{C}$. The crude extract was dried using the oven at below $45^{\circ} \mathrm{C}$. The aqueous extracts were obtained by soaking $25 \mathrm{~g}$ of each of leaves and roots respectively in round bottom flasks containing $200 \mathrm{ml}$ of distilled water. The samples were concentrated using lyophilizer (Model 912A, USA) at 10 ${ }^{-1}$ Torr .

\subsubsection{In vitro Antioxidant Assay}

The In vitro antioxidant activities of Sida corymbosa extracts were determined using different assay techniques.

i. 2,2'-Diphenyl-1-picrylhydrazyl (DPPH) Radical Scavenging Assay.

Diphenyl-picrylhydrazyl (DPPH) radical scavenging effects of the ethanolic and aqueous extracts of Sida corymbosa leaves and root extracts were determined according to the method described by Shwetha and Sudha, [23] and Kalita et al., [24].

Principle

Antioxidants reduce the free radicals of DPPH, thereby reducing its colour to yellow whose absorbance is measured spectrophotometric ally at $517 \mathrm{~nm}$.

Procedure

Serial dilution of each sample $(31.25,62.50,125,250,500$ and $1000 \mathrm{mg} / \mathrm{ml}$ ) was filtered using What man number 125 $\mathrm{mm}$ filter paper and $4 \mathrm{ml}$ of this was mixed with $1 \mathrm{ml}$ of DPPH radical reagent. Exact serial concentrations of ascorbic acid were used as standard. The mixtures were shaken and incubated for $30 \mathrm{~min}$ at room temperature. The absorbance was measured at $517 \mathrm{~nm}$ using UV-VIS spectrophotometer (Model 752, China).

Calculations:

$$
\% \text { inhibition }=\frac{A_{0}-A_{1}}{A_{0}} \times 100(\%)
$$

Where $\mathrm{A}_{0}=$ absorbance of blank (DPPH reagent without extract),

$\mathrm{A}_{1}=$ absorbance of test. Ascorbic acid was used as standard.

Where $\mathrm{A}_{0}=$ absorbance of blank (DPPH reagent without extract),

$\mathrm{A}_{1}=$ absorbance of test. Ascorbic acid was used as standard.

ii. Chelating ion effect assay

The ability of the extracts to chelate ferrous ions was determined according to the method described by Kalita et al., [24].

\section{Principle}


Ferrozine forms red coloured complexes with ferrous iron $\left(\mathrm{Fe}^{2+}\right)$. In the presence of cheating agents, the complex formed is disrupted and the red coloured complexes fade. Measurement of colour reduction is therefore used to determine the chelating activity of an antioxidant.

Procedure

Serial dilutions of the extracts $(31.25,62.50,125,250,500$ and $1000 \mathrm{mg} / \mathrm{ml}$ ) was each filtered. Two mills each of the filtrate was added to a solution of $0.05 \mathrm{ml}$ of ferrous chloride $\left(\mathrm{FeCl}_{2}\right)$. This was followed by the addition of $0.2 \mathrm{ml}$ of ferrozine. The mixture was shaken and incubated at room temperature for 10mins. The absorbance of the solution was measured spectrophotometrically at $562 \mathrm{~nm}$. The percentage inhibition of ferrozine complex formed was calculated as:

$$
\% \text { inhibition }=\frac{A_{0}-A_{1}}{A_{0}} \times 100(\%)
$$

Where $\mathrm{A}_{0}=$ absorbance of blank

$\mathrm{A} 1=$ absorbance of the test.

iii. Ferric reducing antioxidant properties (FRAP) assay

The FRAP assay was used to determine the reducing capacities of the extracts according to the method described by Shwetha and Sudha, [23].

Principle

Antioxidants reduce ferric iron in the presence of 2, 4, 6-Tris (1-pyridyl) -5-triazine (TPTZ) prepared in sodium acetate buffer, ( $\mathrm{pH}$ 3.6) (FRAP reagent). This will result in the formation of a blue complex (ferrous-TPTZ complex) whose absorbance is measured at $593 \mathrm{~nm}$.

Procedure

Nine hundred microlitre of FRAP reagent were mixed with $90 \mathrm{ml}$ of distilled water and $30 \mathrm{ml}$ of various concentration of the extracts $(31.25,62.50,125,250,500$ and $1000 \mathrm{mg} / \mathrm{ml})$. The reaction mixture was incubated at $37^{\circ} \mathrm{C}$ for $30 \mathrm{~min}$ using incubator (model DNP-9052A, China) and the absorbance was measured at $593 \mathrm{~nm}$ using UV-Vis spectrophotometer (model 752, China).

Calculation

The percentage inhibition of ferrous-TPTZ complex formed was calculated using:

$$
\frac{A_{0}-A_{1}}{A_{0}} \times 100(\%)
$$

Where $\mathrm{A}_{0}=$ absorbance of blank (Reagent solution without extracts)

A1=absorbance of test (Reagent solution with extract)

iv. Hydroxyl Radical Scavenging Assay

The hydroxyl radical scavenging activities of the extracts were determined according to the method described by Shwetha and Sudha, [23].

Principle

The hydroxyl radical scavenging activities was assessed based on the ability of S. corymbosa extracts to compete with salicylic acid for hydroxyl radicals in the hydroxyl generating or detecting system thereby developing a pink colour whose absorbance is measured at $562 \mathrm{~nm}$.

Procedure
One mill of $\mathrm{FeSO}_{4}$ was added to $0.7 \mathrm{ml}$ of hydrogen peroxide, $0.3 \mathrm{ml}$ of sodium salicylate and $1 \mathrm{ml}$ of various concentrations of the extracts $(31.25,62.50,125,250,500$ and $1000 \mathrm{mg} / \mathrm{ml}$ ). The mixture was shaken vigorously and incubated for $1 \mathrm{~h}$ at $37^{\circ} \mathrm{C}$ using incubator (model DNP-9052A). After the incubation, the absorbance of the hydroxylated salicyclate complex was measured at $562 \mathrm{~nm}$ spectrophotometrically. The scavenging activity of hydroxyl radical effect was calculated as follows:

$$
\text { Radical scavenging effect }=1-\left[\frac{\left(A_{1}-A_{2}\right)}{A_{0}}\right] \times 100 \%
$$

Where $\mathrm{A}_{1}=$ absorbance in the presence of the extract,

$\mathrm{A}_{2}=$ absorbance without sodium salicylate,

$\mathrm{A}_{0}=$ absorbance of blank (absorbance without extracts).

v. Total antioxidant capacity by phosphomolybdenum assay

This was done according to the method described by Shwetha and Sudha, [23], Aliyu et al., [25],

Principle

The assay is based on the reduction of molybdenum six [Mo (vi)] to molybdenum five [Mo (v)] by the extracts and subsequent formation of green phosphate $[\mathrm{Mo}(\mathrm{v})]$ complex at acidic $\mathrm{pH}$.

Procedure

The ascorbic acid standard was prepared by dissolving 10 $\mathrm{mg}$ of ascorbic acid in $10 \mathrm{ml}$ of distilled water. Stock solution of extracts was prepared by dissolving $10 \mathrm{mg}$ of various extracts in $10 \mathrm{ml}$ methanol. An aliquot of $0.3 \mathrm{ml}$ of each of ethanolic and aqueous root and leaf extracts of Sida corymbosa were each filtered and mixed with $3 \mathrm{ml}$ of reagent solution $\left(0.6 \mathrm{M} \mathrm{H}_{2} \mathrm{SO}_{4}, 28 \mathrm{Mm}\right.$ sodium phosphate $\left[\mathrm{NaPO}_{4}\right]$ and $4 \mathrm{mM}$ ammonium molybdate $\left.\left[\mathrm{NH}_{4}\right] 6 \mathrm{MO}_{7} \mathrm{O}_{24}\right)$ in tubes. The tubes were capped and incubated at $95^{\circ} \mathrm{C}$ for $90 \mathrm{~min}$. The absorbance of the reaction mixture was measured at $695 \mathrm{~nm}$ using a UV-VIS spectrophotometer (Model 752, China) against blank after it has been cooled to room temperature. Methanol was used in the place of extract as the reagent blank. A calibration curve of ascorbic acid standard was prepared by diluting ascorbic acid standard solutions to $31.25,62.50,125$, 250,500 and $1000 \mathrm{mg} / \mathrm{ml}$ with absolute methanol. This was followed by the addition of reagents for total antioxidant capacity in every test tube for the serial dilutions as was done above in the plant's extracts.

Calculations:

Concentration values of the extracts were read off from the ascorbic acid standard curve by interpolating to the $\mathrm{x}$-axis and this is equivalent to the total antioxidant capacities of the extracts (ethanol and aqueous extracts of the leaf and root).

\subsubsection{Animal Studies}

i. Determination of acute toxicity level $\left(\mathrm{LD}_{50}\right)$

The acute toxicity level of the Sida corymbosa ethanolic leaf extract was determined using a new method for determining acute toxicity in experimental animal models according to Enegide et al., [26]. This was done in three stages. Four rats were used in the first stage. The extract was 
administered to the rats orally using oral cannula. The rats were grouped into four groups with each group containing one rat. Group one was administered $10 \mathrm{mg} / \mathrm{kgbdw}$ of the extract, while groups two, three and four were each administered 100 , 300 and $600 \mathrm{mg} / \mathrm{kgbw}$ of the extract respectively. Since no mortality and signs of toxicity were observed at this stage, another three groups of rats with one rat in each group were administered 1000, 1,500 and 2,000 mg/kgbw (stage two). No mortality and signs of toxicity were observed. Based on this, another three groups of rats with one rat in each group were administered 3,000, 4,000 and 5,000 $\mathrm{mg} / \mathrm{kgbw}$ of the extract respectively (stage three). Mortality and signs of toxicity were not observed at $5,000 \mathrm{mg} / \mathrm{kgbw}$. As a result of this, a confirmatory test was carried out according to the method described by Enegide et al., ${ }^{26}$, by administering 5,000 $\mathrm{mg} / \mathrm{kgbw}$ of the extract to each of two groups of one rat each. The Observation was made on the rats for $1 \mathrm{~h}$ after administration of extract and $10 \mathrm{~min}$ for every $2 \mathrm{~h}$ interval for $24 \mathrm{~h}$.

Calculation:

$$
\mathrm{LD}_{50}=\frac{\left[\mathrm{M}_{0}+\mathrm{M}_{1}\right]}{2}
$$

Where $\mathrm{M}_{0}=$ Highest dose of the test substance that gave no mortality $=0$

$\mathrm{M}_{1}=$ Lowest dose of the test substance that gave mortality $=0$

Since no mortality and signs of toxicity were shown up to $5000 \mathrm{mg} / \mathrm{kgbw}$ of the extract, therefore, $\mathrm{LD}_{50}=0$.

ii. Animal Handling

Animal care and handling were done according to guidelines given by WHO, [27] and Ethical Committee of Faculty of Basic Medical Sciences, College of Health Sciences, Nnamdi Azikiwe University, Nnewi Campus. The rats were kept in metal cages, given water and feed ad libitum. They were acclimatized for three weeks, housed under the same condition of humidity and temperature. They were also kept under $12 \mathrm{~h}$ of light and dark cycle.

iii. Experimental design

A total of 160 male-adult Albino Wistar rats of about 12 weeks old weighing 180-200g each were used. Based on the outcome of toxicity test, the rats were grouped as follows:

Group A: Positive control group- those given feed and water only from 7 to $28 \mathrm{~d}$ (normal rats)

Group B: Negative control group- rats $+\mathrm{CCl}_{4}$ only and left for 7 to $28 \mathrm{~d}$ (untreated group)

Group C: Rats administered $5000 \mathrm{mg} / \mathrm{kgbw}$ of Sida corymbosa extract for $7 \mathrm{~d}+\mathrm{CCl}_{4}$ and left for $7 \mathrm{~d}$ to $28 \mathrm{~d}$ (Protective studies)

Group D: Rats administered $3000 \mathrm{mg} / \mathrm{kgbw}$ of Sida corymbosa extract for $7 \mathrm{~d}+\mathrm{CCl}_{4}$ and left for $7 \mathrm{~d}$ to $28 \mathrm{~d}$ (Protective studies)

Group E: Rats administered $1000 \mathrm{mg} / \mathrm{kgbw}$ of Sida corymbosa extract for 7 days $+\mathrm{CCl}_{4}$ and left for $7 \mathrm{~d}$ to $28 \mathrm{~d}$ (Protective studies)

Group F: Rats administered $\mathrm{CCl}_{4}+5000 \mathrm{mg} / \mathrm{kgbw}$ of extract for 7 to $28 \mathrm{~d}$ (Curative studies)

Group G: Rats administered $\mathrm{CCl}_{4}+3000 \mathrm{mg} / \mathrm{kgbw}$ of extract for 7 to $28 \mathrm{~d}$ (Curative studies)

Group H: Rats administered $\mathrm{CCl}_{4}+1000 \mathrm{mg} / \mathrm{kgbw}$ of extract for $7 \mathrm{~d}$ to $28 \mathrm{~d}$ (Curative studies)

\subsubsection{Serum Antioxidant Assay}

i. Determination of reduced glutathione (GSH)

Reduced glutathione was determined by using UV-VIS spectrophotometer (Model 752G, China) according to the method of Beutiler, [28].

Principle

This method was based on the development of yellow colour when 5, 5'-dithio-bis-2-nitrobenzoic (DTNB) acid was added to compound containing sulphydryl groups. The colour developed was read at $412 \mathrm{~nm}$ in a spectrophotometer.

Procedure

Two hundred microlitre of serum was mixed with $1.8 \mathrm{ml}$ of EDTA solution. This was followed by the addition of $3.0 \mathrm{ml}$ of precipitating reagent, mixed thoroughly and kept for $5 \mathrm{~min}$ before centrifugation. After this, $2 \mathrm{ml}$ of the filtrate, $4 \mathrm{ml}$ of $0.3 \mathrm{M}$ disodium hydrogen phosphate solution and $1 \mathrm{ml}$ of DTNB reagent were added and the colour developed was read at $412 \mathrm{~nm}$ in a spectrophotometer. Standard solutions containing 10 and $20 \mathrm{mg} / \mathrm{dl}$ of reduced glutathione were treated similarly. The values were expressed as $\mathrm{mg} / \mathrm{dl}$ for plasma.

Calculation:

$$
\text { Conc of GSH }(\mu \mathrm{mol} / 1)=\frac{\text { Abs test }}{\text { Abs STD }} \times \text { Conc of STD }
$$

\section{Abs=absorbance (6)}

Conc $=$ concentration

$\mathrm{STD}=$ standard

ii. Estimation of serum glutathione peroxidase (GPx) activities

The activity of glutathione peroxidase was determined by using UV-VIS spectrophotometer (Model 752G, China) according to the method of Rotruk et al; [29].

Principle

Glutathione peroxidase in the presence of hydrogen peroxide $\left(\mathrm{H}_{2} \mathrm{O}_{2}\right)$ oxidizes reduced glutathione ( $\left.\mathrm{GSH}\right)$ to form $\mathrm{H}_{2} \mathrm{O}$. The amount of GSH consumed is directly proportional to the activity of GPx and it is expressed as $\mathrm{U} / \mathrm{ml}(\mu \mathrm{mol}$ of GSH consumed/minute). The GSH remains after the reaction is allowed to react with 5'-5' dithiobis-2-nitrobenzoic acid (DTNB) to form a yellow complex that absorbs maximally at $412 \mathrm{~nm}$.

$$
2 \mathrm{GSH}+\mathrm{H}_{2} \mathrm{O}_{2} \stackrel{\mathrm{GPx}}{\longrightarrow} \mathrm{GSSG}+2 \mathrm{H}_{2} \mathrm{O}
$$

Procedure

Three test tubes were marked "Test", "Standard" and "Blank".

Four hundred microlitre $(0.4 \mathrm{ml})$ of phosphate buffer $(\mathrm{pH}$ 7.0 ) and $0.1 \mathrm{ml}$ sodium azide were added to all test tubes. This was followed by the addition of $0.2 \mathrm{ml}$ of the plasma to test tube marked "Test", $0.2 \mathrm{ml}$ of GSH standard $(0.651 \mu \mathrm{mol} / \mathrm{ml})$ to test tube marked "Standard, $0.2 \mathrm{ml}$ distilled water to test tube marked "Blank" and $0.1 \mathrm{ml}$ of $\mathrm{H}_{2} \mathrm{O}_{2}$ to all the test tubes. 
The resulting solution was thoroughly mixed and incubated at $37^{\circ} \mathrm{C}$ for $10 \mathrm{~min}$. The reaction was arrested by the addition of $0.4 \mathrm{ml}$ of $10 \%$ trichloroacetic acid (TCA). The tubes were centrifuged at $4000 \mathrm{rpm}$ for 5 minutes. Thereafter, another 3 sets of test tubes for standard, test and blank were arranged. Five hundred microliter $(0.5 \mathrm{ml})$ each of supernatants for sample, standard and blank were added into the clean test tube for test, standard and blank. This was followed by the addition of $2 \mathrm{ml}$ of phosphate buffer $(\mathrm{pH} \mathrm{7.0)}$ and $0.5 \mathrm{ml}$ of $40 \mathrm{mM}$ DTNB. The solution was thoroughly mixed and the resulting yellow colour was read at $412 \mathrm{~nm}$.

Calculation:

The activity of glutathione peroxidase was expressed as $\mathrm{U} / \mathrm{ml}$ of plasma ( $\mu$ moles of GSH utilized/ minute).

$$
\begin{aligned}
& \text { Actual Test OD=OD Blank - OD Test } \\
& \text { Actual STD OD }=\text { OD STD - OD Blank. }
\end{aligned}
$$$$
\text { GPx activity }=\frac{\text { Actual OD Test }}{\text { Actual OD STD }} \times \text { STD Conc }(\mathrm{U} / \mathrm{mL})
$$

iii. Estimation of serum catalase activities

The activity of catalase was determined according to the standard method described by Hadwan and Abed, [30] by using UV-VIS spectrophotometer (Model 752G, China).

Principle

Catalase catalyzes the following reaction:

$$
2 \mathrm{H}_{2} \mathrm{O}_{2} \mathrm{e} \stackrel{\text { Catalase }}{\longrightarrow} 2 \mathrm{H}_{2}+\mathrm{O}_{2}
$$

Catalase activity was assessed by incubating the enzyme sample in substrate hydrogen peroxide in the sodiumpotassium phosphate buffer, $(\mathrm{pH} 7.4)$ at $37^{\circ} \mathrm{C}$ for three minutes. The reaction was stopped with ammonium molybdate. Absorbance of the yellow complex of molybdate and hydrogen peroxide was measured at $374 \mathrm{~nm}$ against the blank and this is equivalent to the activities of catalase in the serum.

Procedure

Four clean test tubes were provided for: test, control-test, standard and blank respectively. Hundred microlitres of serum and distilled water was each added into test and control-test tubes. This was followed by the addition of hundred microlitre of standard into standard tubes. One mill of distilled water was added into control-test tube while one mill of hydrogen peroxide was added into test and standard tubes. The tubes were incubated at $37^{\circ} \mathrm{C}$ for 3 minutes. This was followed by the addition of $4 \mathrm{ml}$ of ammonium molybdate into all the tubes and the changes in absorbance were recorded at $374 \mathrm{~nm}$ against the reagent blank.

Calculation:

Catalase activity of test in $\mathrm{U} / \mathrm{l}=2.303 / \mathrm{t} \times\left(\operatorname{logs} \mathrm{S}^{\circ} / \mathrm{S}-\mathrm{M}\right) \mathrm{x}$ $\mathrm{Vt} / \mathrm{Vs}$.

Where $\mathrm{t}=$ time, $\mathrm{S}^{\circ}=$ absorbance of standard tube, $\mathrm{S}=$ absorbance of test tube, $\mathrm{M}=\mathrm{absorb}$ ance of control-test (correction factor), $\mathrm{Vt}=$ total volume of reagents in test tube and $\mathrm{Vs}=$ volume of serum. iv. Determination of serum supraoxide dismutase (SOD) activities

Supraoxide dismutase was assayed by using UV-VIS spectrophotometer (Model 752G, China) according to the standard method of Rotruk et al., [29].

Principle

The ability of superoxide dismutase (SOD) to inhibit the autooxidation of adrenaline at $\mathrm{pH} 10.2$ makes this reaction a basis for the SOD assay. Superoxide anion $\left(02^{-}\right)$generated by the xanthine oxidase reaction is known to cause the oxidation of adrenaline to adrenochrome. The yield of adrenochrome produced per superoxide anion introduced increased with increasing $\mathrm{pH}$ and concentration of adrenaline.

Procedure

Eighty microliter of sample was added in a test tube marked "Test". This was followed by the addition of $1000 \mu \mathrm{l}$ of carbonate buffer ( $\mathrm{pH}$ 10.2). The resulting solution was mixed thoroughly, and allowed to equilibrate by incubating at $37^{\circ} \mathrm{C}$ for $5 \mathrm{~min}$. Thereafter, $600 \mu \mathrm{l}$ of freshly prepared epinephrine was added and the reaction mixture was read at 30 seconds interval for $150 \mathrm{~s}$ at $480 \mathrm{~nm}$. The blank was treated the same way except that 80 ul of distilled water was added to test tube marked "Blank" instead of serum. The changes in absorbances of both test and blank were determined. The $\%$ inhibition of auto oxidation of epinephrine by SOD was calculated and the serum SOD activity was expressed as U/ml. One unit of SOD activity was equivalent to the amount of SOD that can cause $50 \%$ inhibition of epinephrine.

Calculation:

$$
\% \text { inhibition }=\frac{\text { OD blank }- \text { OD test }}{\text { OD blank }} \times 00(\%)
$$

Enzyme Unit $(\mathrm{U} / \mathrm{ml})=(\%$ inhibition $/ 50) X$ dilution factor. $\mathrm{OD}=$ Optical density

v. Estimation of serum total antioxidant

Ferric antioxidant properties (FRAP) of plasma was determined by using UV-VIS spectrophotometer (Model $752 \mathrm{G}$, China) according to the method described by Benzie and Strain, [31].

Principle

At low $\mathrm{pH}$, antioxidant power causes the reduction of ferric tripyridyl triazine (Fe III -TPTZ) complex to ferrous form (which has an intense blue colour) that can be monitored by measuring the change in absorption at $593 \mathrm{~nm}$. Ferric reducing ability of plasma (FRAP) values were obtained by comparing the absorbance change at $593 \mathrm{~nm}$ in mixture (test) with those containing ferrous ion in known concentration (Standard) and this represents total antioxidant in the serum.

Procedure

A working reagent comprising acetate buffer $(\mathrm{pH} 3.6)$, ferric chloride and tripyridyltriazine in the ratio of 10:1:1 respectively was prepared. Sixty microlitres each of samples and standard were added into test tubes for samples and standard respectively. This was followed by the addition of $1.8 \mathrm{ml}$ of the working reagent to all the test tubes. The reaction mixture was mixed thoroughly, and incubated at $37^{\circ} \mathrm{C}$ for 10 min. The resulting blue coloured solution developed was then 
read at $593 \mathrm{~nm}$. The blank was treated the same way except that $60 \mathrm{ul}$ of distilled water was added the test tube for blank instead of plasma. The standard solution contains $1000 \mu \mathrm{mol} / 1$ of ferrous sulphate.

Calculation:

$$
\frac{\text { Abs test }}{\text { Abs STD }} \times \text { Conc of STD }(1000 \mu \mathrm{mol} / \mathrm{l})
$$

vi. Determination of serum malondialdehyde (MDA) level Malondialdehyde MDA level was determined by using UV-VIS spectrophotometer (Model 752G, China) according to the method of Alam and Fareed [32].

Principle

Malondialdehyde (MDA) is a product of lipid peroxidation. When heated with 2-thiobarbituric acid (TBA) under alkaline condition, it forms a pink coloured product, which has an absorption maximum at $532 \mu \mathrm{m}$. The intensity of colour generated is directly proportional to the concentration of MDA in the sample.

Procedure

Hundred microlitre of serum was added in the test tube for test. This was followed by the addition of $1 \mathrm{ml}$ of thiobarbituric acid dissolved in alkaline medium (sodium hydroxide). The mixture was mixed thoroughly and $1 \mathrm{ml}$ of glacial acetic acid was added to the mixture. The reaction mixture was also shaken thoroughly and incubated in boiling water $\left(100^{\circ} \mathrm{C}\right)$ for 15 minutes. It was allowed to cool and the turbidity removed by centrifugation at $3000 \mathrm{rpm}$ for 10 minutes at $25^{\circ} \mathrm{C}$. Thereafter, the absorbance of the supernatant was read at $532 \mathrm{~nm}$. The same volume of TBA and glacial acetic acid was added to the blank, but $0.1 \mathrm{ml}$ of distilled water was added to the blank instead of plasma. The level of MDA in the serum is expressed as $\mathrm{nmol} / \mathrm{ml}$ using the molar extinction coefficient for MDA (1.56x105 M-1cm-1).

Calculation:

$$
\text { MDA }(\mathrm{nmol} / \mathrm{ml})=(\mathrm{OD} X 1000000) / \mathrm{E} 532
$$

Where E532=Molar extinction coefficient for MDA $\left(1.56 \times 105 \mathrm{M}^{-1} \mathrm{~cm}^{-1}\right)$

\subsubsection{Statistical Analysis of Results}

Results obtained were expressed as mean \pm SD of triplicate determinations. Graphs, students' T-test and one-way analysis of ANOVA were used to analyze results using SPSS statistical software (version 21). Significant difference was tested at 0.05 level of significance.

\section{Results}

Tables 1-5 shows the results of in vitro antioxidant activities of Sida corymbosa extracts using different methods at various concentrations (1000, 500, 250, 125, 62.5 and 31.25 $\mathrm{mg} / \mathrm{ml}$ ). The ethanolic leaf, aqueous leaf, ethanolic root and aqueous root extracts showed higher percent inhibition significantly $(\mathrm{P}<0.05)$ as the concentrations increased from $31.25 \mathrm{mg} / \mathrm{ml}$ to $1000 \mathrm{mg} / \mathrm{ml}$ using DPPH radical scavenging assay, FRAP assay, hydroxyl radical scavenging assay and chelating iron effect assay (tables 1-4). Vitamin C standard showed the highest percentage inhibition using DPPH assay followed by ethanolic leaf extract of Sida corymbosa while ethanolic root extract showed the least percentage inhibition (table 1).

\begin{tabular}{|c|c|c|c|c|c|}
\hline \multirow{2}{*}{$\begin{array}{l}\text { Conc of extract } \\
(\mathrm{mg} / \mathrm{ml})\end{array}$} & \multicolumn{2}{|l|}{ Root extract } & \multicolumn{2}{|l|}{ Leaf extract } & \multirow[t]{2}{*}{ Vit C } \\
\hline & Aqueous & Ethanol & Aqueous & Ethanol & \\
\hline 1000 & $70.02 \pm 0.0^{\mathrm{abcd}}$ & $34.89 \pm 0.30^{\text {abcd }}$ & $86.26 \pm 0.11^{\mathrm{abc}}$ & $93.98 \pm 0.34^{\mathrm{abc}}$ & $94.75 \pm 0.08^{d}$ \\
\hline 500 & $67.63 \pm 0.17^{\mathrm{abcd}}$ & $29.38 \pm 0.20^{\mathrm{abcd}}$ & $85.97 \pm 0.18^{a b c}$ & $93.84 \pm 0.09^{\mathrm{abc}}$ & $96.09 \pm 0.12^{\mathrm{d}}$ \\
\hline 250 & $66.36 \pm 0.08^{\mathrm{abcd}}$ & $28.47 \pm 0.30^{\mathrm{abcd}}$ & $85.13 \pm 0.46^{\mathrm{abc}}$ & $93.61 \pm 0.09^{\mathrm{abc}}$ & $95.75 \pm 0.09^{d}$ \\
\hline 125 & $65.50 \pm 0.23^{\mathrm{abcd}}$ & $27.95 \pm 0.30^{\mathrm{abcd}}$ & $82.74 \pm 0.46^{\mathrm{abc}}$ & $92.11 \pm 0.09^{\mathrm{abc}}$ & $94.75 \pm 0.09^{d}$ \\
\hline 62.50 & $64.36 \pm 0.21^{\mathrm{abcd}}$ & $82.40 \pm 0.02^{\mathrm{abc}}$ & $82.40 \pm 0.02^{\mathrm{abc}}$ & $91.35 \pm 0.09^{\mathrm{abc}}$ & $93.39 \pm 0.09^{d}$ \\
\hline 31.25 & $63.88 \pm 0.27^{\mathrm{abcd}}$ & $86.26 \pm 0.11^{\text {abcd }}$ & $86.26 \pm 0.14^{\mathrm{abc}}$ & $86.81 \pm 0.92^{\mathrm{abc}}$ & $90.83 \pm 0.10^{\mathrm{d}}$ \\
\hline
\end{tabular}

Table 1. Percentage inhibition of Sida corymbosa root and leaf extracts using 2, 2'-Diphenyl-1-picrylhydrazyl (DPPH) radical scavenging assay.

Values above are means of triplicate determination $\pm \mathrm{SD}$. Values in the same raw and column, having the same letters are statistically different $(\mathrm{P}<0.05)$. One way analysis of ANOVA was used in analysing the results.

$\mathrm{a}=$ comparism of values among various concentrations

$\mathrm{b}=$ comparism within extracts (aqueous root vs ethanolic root extracts and aqueous leaf vs ethanolic leaf extracts)

$\mathrm{c}=$ comparism among various extracts (ethanolic leaf extract vs aqueous and ethanolic root extracts)

$\mathrm{d}=$ comparism between $\mathrm{Vit} \mathrm{C}$ standard and various extracts

For chelating iron effect, aqueous leaf extract showed the highest percentage inhibition at $1000 \mathrm{mg} / \mathrm{ml}$ followed by EDTA standard (table 2). For FRAP assay, ethanolic and aqueous leaf extracts showed the highest percentage inhibition, followed by trolex standard while ethanolic and aqueous root extracts showed lower percentage inhibition table 3).

Table 2. Percentage inhibition of Sida corymbosa root and leaf extracts using chelating iron effect assay.

\begin{tabular}{lllll}
\hline $\begin{array}{l}\text { Conc of extract } \\
(\mathbf{m g} / \mathbf{m l})\end{array}$ & Root extract & Leaf extract & EDTA \\
\cline { 2 - 5 } & Aqueous & Ethanol & Aqueous & Ethanol \\
\hline 1000 & $62.01 \pm 0.56^{\text {abcd }}$ & $22.53 \pm 0.23^{\text {abcd }}$ & $98.36 \pm 0.99^{\text {abcd }}$ & $90.31 \pm 0.99^{\text {abcd }}$ \\
500 & $48.51 \pm 0.85^{\text {abcd }}$ & $21.19 \pm 0.36^{\text {abcd }}$ & $81.29 \pm 1.66^{\text {abc }}$ & $87.18 \pm 0.86^{\text {abc }}$ \\
250 & $40.13 \pm 0.13^{\text {abcd }}$ & $18.75 \pm 0.20^{\text {abcd }}$ & $78.74 \pm 1.00^{\text {abc }}$ & $82.62 \pm 10.30^{\text {abc }}$ \\
125 & $27.28 \pm 0.70^{\text {abcd }}$ & $17.71 \pm 0.30^{\text {abcd }}$ & $62.57 \pm 0.52^{\text {abc }}$ & $94.11 \pm 0.02^{\text {d }}$ \\
\hline
\end{tabular}




\begin{tabular}{lllll}
\hline $\begin{array}{l}\text { Conc of extract } \\
(\mathbf{m g} / \mathbf{m l})\end{array}$ & Root extract & Leaf extract & EDTA \\
\cline { 2 - 5 } & Aqueous & Ethanol & Aqueous & Ethanol \\
\hline 62.50 & $25.98 \pm 0.28^{\text {abcd }}$ & $16.67 \pm 0.30^{\text {abcd }}$ & $57.11 \pm 0.95^{\text {abcd }}$ & $70.09 \pm 2.57^{\text {abcd }}$ \\
31.25 & $7.73 \pm 0.42^{\text {abcd }}$ & $15.49 \pm 0.30^{\text {abcd }}$ & $43.71 \pm 2.64^{\text {abcd }}$ & $60.96 \pm 4.30^{\text {abc }}$ \\
\hline
\end{tabular}

Values above are means of triplicate determination \pm SD. Values in the same raw and column, having the same letters are statistically different $(\mathrm{P}<0.05)$. One way analysis of ANOVA was used in analysing the results.

$\mathrm{a}=$ comparism of values among various concentrations

$\mathrm{b}=$ comparism within extracts (aqueous root vs ethanolic root extracts and aqueous leaf vs ethanolic leaf extracts)

$\mathrm{c}=$ comparism among various extracts (ethanolic leaf extract vs aqueous and ethanolic root extracts)

$\mathrm{d}=$ comparism between Vit $\mathrm{C}$ standard and various extracts

Table 3. Percentage inhibition of Sida corymbosa root and leaf extracts using ferric chloride antioxidant properties (FRAP) assay.

\begin{tabular}{llllll}
\hline $\begin{array}{l}\text { Conc of extract } \\
(\mathbf{m g} / \mathbf{m l})\end{array}$ & Root extract & Leaf extract & Trolex \\
\cline { 2 - 6 } & Aqueous & Ethanol & Aqueous & Ethanol & \\
\hline 1000 & $41.66 \pm 0.33^{\text {abcd }}$ & $9.60 \pm 0.62^{\text {abcd }}$ & $97.66 \pm 0.37^{\text {abcd }}$ & $98.04 \pm 0.80^{\text {abcd }}$ & $89.90 \pm 0.27^{\text {d }}$ \\
500 & $38.22 \pm 0.42^{\text {abcd }}$ & $1.96 \pm 0.47^{\text {abcd }}$ & $96.94 \pm 3.13^{\text {abc }}$ & $95.69 \pm 0.90^{\text {abcd }}$ & $81.07 \pm 1.20^{\mathrm{d}}$ \\
250 & $37.47 \pm 0.13^{\text {abcd }}$ & $1.55 \pm 0.31^{\text {abcd }}$ & $87.20 \pm 3.10^{\text {abc }}$ & $91.57 \pm 2.38^{\text {abcd }}$ & $74.26 \pm 0.26^{\mathrm{d}}$ \\
125 & $36.57 \pm 0.41^{\text {abcd }}$ & $1.53 \pm 0.31^{\text {abcd }}$ & $84.16 \pm 2.69^{\text {abcd }}$ & $86.86 \pm 1.48^{\text {abcd }}$ & $70.27 \pm 0.16^{\mathrm{d}}$ \\
62.50 & $19.83 \pm 0.42^{\text {abcd }}$ & $1.45 \pm 0.18^{\text {abcd }}$ & $82.13 \pm 2.40^{\text {abcd }}$ & $77.06 \pm 6.14^{\text {abcd }}$ & $63.79 \pm 0.48^{\mathrm{d}}$ \\
31.25 & $17.75 \pm 0.10^{\text {abcd }}$ & $0.62 \pm 0.30^{\text {abcd }}$ & $75.33 \pm 0.74^{\text {abcd }}$ & $26.08 \pm 0.34^{\text {abcd }}$ & $60.92 \pm 0.46^{\mathrm{d}}$ \\
\hline
\end{tabular}

Values above are means of triplicate determination $\pm \mathrm{SD}$. Values in the same raw and column, having the same letters are statistically different $(\mathrm{P}<0.05)$. One way analysis of ANOVA was used in analysing the results.

$\mathrm{a}=$ comparism of values among various concentrations

$\mathrm{b}=$ comparism within extracts (aqueous root vs ethanolic root extracts and aqueous leaf vs ethanolic leaf extracts)

$\mathrm{c}=$ comparism among various extracts (ethanolic leaf extract vs aqueous and ethanolic root extracts)

$\mathrm{d}=$ comparism between Vit $\mathrm{C}$ standard and various extracts

For hydroxyl radical scavenging assay, aqueous leaf extract showed the highest percentage inhibition, followed by quercitin standard and aqueous root extract. While ethanolic leaf extract showed the least percentage inhibition (table 4).

Table 4. Percentage inhibition of Sida corymbosa root and leaf extracts using hydroxyl radical scavenging assay.

\begin{tabular}{llllll}
\hline $\begin{array}{l}\text { Conc of extract } \\
(\mathbf{m g} / \mathbf{m l})\end{array}$ & Root extract & \multicolumn{2}{l}{ Leaf extract } & Trolex \\
\cline { 2 - 6 } & Aqueous & Ethanol & Aqueous & Ethanol & \\
\hline 1000 & $70.06 \pm 3.91^{\text {abcd }}$ & $34.89 \pm 0.30^{\text {abcd }}$ & $93.48 \pm 0.73^{\text {abcd }}$ & $29.94 \pm 1.42^{\text {abcd }}$ & $86.86 \pm 1.27^{\text {d }}$ \\
500 & $66.87 \pm 1.13^{\text {abcd }}$ & $29.38 \pm 0.20^{\text {abcd }}$ & $92.03 \pm 0.00^{\text {abc }}$ & $19.44 \pm 0.93^{\text {abcd }}$ & $75.40 \pm 0.53^{\text {d }}$ \\
250 & $66.27 \pm 0.46^{\text {abcd }}$ & $28.47 \pm 0.30^{\text {abcd }}$ & $92.27 \pm 3.27^{\text {abc }}$ & $9.26 \pm 1.85^{\text {abcd }}$ & $71.71 \pm 0.56^{\mathrm{d}}$ \\
125 & $64.99 \pm 0.60^{\text {abcd }}$ & $27.95 \pm 0.30^{\text {abcd }}$ & $87.20 \pm 1.11^{\text {abcd }}$ & $6.48 \pm 0.93^{\text {abcd }}$ & $60.77 \pm 0.21^{\text {d }}$ \\
62.50 & $58.93 \pm 0.97^{\text {abcd }}$ & $26.78 \pm 0.30^{\text {abcd }}$ & $83.82 \pm 1.83^{\text {abcd }}$ & $4.32 . \pm 0.54^{\text {abcd }}$ & $56.74 \pm 0.49^{\text {d }}$ \\
31.25 & $52.90 \pm 0.75^{\text {abcd }}$ & $25.03 \pm 0.30^{\text {abcd }}$ & $76.09 \pm 1.45^{\text {abcd }}$ & $2.47 \pm 0.54^{\text {abcd }}$ & $54.86 \pm 0.08^{\text {d }}$ \\
\hline
\end{tabular}

Values above are means of triplicate determination \pm SD. Values in the same raw and column, having the same letters are statistically different $(\mathrm{P}<0.05)$. One way analysis of ANOVA was used in analysing the results.

$\mathrm{a}=$ comparism of values among various concentrations

$\mathrm{b}=$ comparism within extracts (aqueous root vs ethanolic root extracts and aqueous leaf vs ethanolic leaf extracts)

$\mathrm{c}=$ comparism among various extracts (ethanolic leaf extract vs aqueous and ethanolic root extracts)

$\mathrm{d}=$ comparism between Vit $\mathrm{C}$ standard and various extracts

Total antioxidant capacity (TAC) assay carried out revealed that ethanolic leaf extract of Sida corymbosa had the highest total antioxidant capacity, followed by aqueous leaf extract and ethanolic root extracts while aqueous root extract had the least total antioxidant capacity (table 5).

Table 5. Total antioxidant capacity (TAC) of Sida corymbosa extracts using phosphomolybdenum assay.

\begin{tabular}{lll}
\hline Sample & Extract & TAC $(\mathbf{m g} / \mathbf{m l})$ \\
\hline \multirow{2}{*}{ Root } & Aqueous & $208.34 \pm 1.23^{\mathrm{ab}}$ \\
& Ethanol & $213.08 \pm 3.21^{\mathrm{ab}}$ \\
Leaf & Aqueous & $223.33 \pm 0.01^{\mathrm{ab}}$ \\
& Ethanol & $773.33 \pm 2.44^{\mathrm{ab}}$ \\
\hline
\end{tabular}

Values above are means of triplicate determination \pm SD. Values in the same column, bearing the same letters are statistically different $(\mathrm{P}<0.05)$. One way analysis of ANOVA was used in analysing the results.

$\mathrm{a}=$ ethanolic leaf extract vs aqueous and ethanolic root extracts

$\mathrm{b}=$ comparism within extracts (aqueous root vs ethanolic root extracts and aqueous leaf vs ethanolic leaf extracts)

The results of serum antioxidants levels in rats given Sida corymbosa ethanolic leaf extract before and after 
administering carbon tetrachloride are hereby presented in tables 6 and 7. For rats administered sida corymbosa ethanolic leaf before administering carbon tetrachloride $\left(\mathrm{CCl}_{4}\right)$, serum reduced glutathione (GSH), glutathione peroxidase (GPx), catalase CAT), supraoxide dismutase (SOD), and total antioxidant capacity levels (TAC) were highest significantly $(\mathrm{P}<0.05)$ in rat in positive control groups (group A), followed by rats in groups $\mathrm{C}$ to $\mathrm{E}$ (rats given $5000 \mathrm{mg} / \mathrm{kg}, 3000 \mathrm{mg} / \mathrm{kg}$ and $1000 \mathrm{mg} / \mathrm{kg}$ ) (table 6). The same trend was maintained in rats administered $\mathrm{CCl}_{4}$ before administering the extract at the same dose (groups F to H) (table 7) while antioxidant levels in rats administered carbon tetrachloride only (group B-negative control group) decreased significantly from 7-28 d). There were no significant differences in the values of GSH among rats given 5000,3000 and $1000 \mathrm{mg} / \mathrm{kgbw}$ of extract before and after $\mathrm{CCl}_{4}$ administration (tables 6 and 7). Assay on serum CAT, SOD and TAC revealed that CAT activities were higher significantly $(\mathrm{P}<0.05)$ in rats given $5000 \mathrm{mg} / \mathrm{kgbw}$ than in those given $1000 \mathrm{mg} / \mathrm{kgbw}$ of the extract at $28 \mathrm{~d}$ of treatment while SOD and TAC levels were higher $(\mathrm{P}<0.05)$ in rats given $5000 \mathrm{mg} / \mathrm{kgbw}$ than in those given $3000 \mathrm{mg} / \mathrm{kgbw}$ of the extract at $28 \mathrm{~d}$, before and after $\mathrm{CCl}_{4}$ administration.

Table 6. Serum antioxidant assay of rats administered Sida corymbosa extract before administering carbon tetrachloride.

\begin{tabular}{|c|c|c|c|c|c|}
\hline Groups & GSH (u/ml) & GPx (u/ml) & CAT (u/ml) & SOD $(\mathbf{u} / \mathbf{m l})$ & TAC (u/ml) \\
\hline \multicolumn{6}{|c|}{ A (positive control) } \\
\hline $7 d$ & $13.50 \pm 1.73^{\mathrm{a}}$ & $0.90 \pm 0.06^{\mathrm{a}}$ & $76.72 \pm 2.96^{\mathrm{a}}$ & $16.10 \pm 4.85^{\mathrm{a}}$ & $820.00 \pm 294.70^{\mathrm{a}}$ \\
\hline $14 \mathrm{~d}$ & $13.43 \pm 1.75^{\mathrm{a}}$ & $0.89 \pm 0.06^{\mathrm{a}}$ & $76.70 \pm 3.00^{\mathrm{a}}$ & $15.93 \pm 5.08^{\mathrm{a}}$ & $821.33 \pm 295.47^{\mathrm{a}}$ \\
\hline $21 \mathrm{~d}$ & $13.42 \pm 1.83^{\mathrm{a}}$ & $0.90 \pm 0.05^{\mathrm{a}}$ & $76.69 \pm 2.94^{\mathrm{a}}$ & $16.30 \pm 4.93^{\mathrm{a}}$ & $823.00 \pm 294.78^{\mathrm{a}}$ \\
\hline $28 \mathrm{~d}$ & $13.50 \pm 1.73^{\mathrm{a}}$ & $0.90 \pm 0.06^{\mathrm{a}}$ & $76.76 \pm 2.82^{\mathrm{a}}$ & $16.33 \pm 4.93^{\mathrm{a}}$ & $821.67 \pm 294.94^{\mathrm{a}}$ \\
\hline \multicolumn{6}{|c|}{$\mathrm{B}$ (Negative control, rats $+\mathrm{CCl}_{4}$ only) } \\
\hline $7 \mathrm{~d}$ & $6.21 \pm 0.05^{\mathrm{ab}}$ & $0.35 \pm 0.00^{\mathrm{ab}}$ & $23.23 \pm 4.97^{\mathrm{ab}}$ & $5.01 \pm 0.02^{\mathrm{ab}}$ & $201.33 \pm 13.31^{\mathrm{ab}}$ \\
\hline $21 \mathrm{~d}$ & $6.20 \pm 0.05^{\mathrm{ab}}$ & $0.35 \pm 0.02^{\mathrm{ab}}$ & $29.39 \pm 4.97^{\mathrm{ab}}$ & $5.01 \pm 0.02^{\mathrm{ab}}$ & $202.33 \pm 13.32^{\mathrm{ab}}$ \\
\hline $28 \mathrm{~d}$ & $6.20 \pm 0.05^{\mathrm{ab}}$ & $0.36 \pm 0.01^{\mathrm{ab}}$ & $29.39 \pm 4.94^{\mathrm{ab}}$ & $5.03 \pm 0.02^{\mathrm{ab}}$ & $202.00 \pm 13.86^{\mathrm{ab}}$ \\
\hline \multicolumn{6}{|c|}{$\mathrm{C}\left(5000 \mathrm{mg} / \mathrm{kgbw}\right.$ extract $\left.+\mathrm{CCl}_{4}\right)$} \\
\hline $7 \mathrm{~d}$ & $10.80 \pm 0.59^{\mathrm{ab}}$ & $0.49 \pm 0.05^{\mathrm{ab}}$ & $57.50 \pm 0.75^{\mathrm{abc}}$ & $11.37 \pm 0.21^{\mathrm{bc}}$ & $578.33 \pm 13.33^{\mathrm{ab}}$ \\
\hline $14 \mathrm{~d}$ & $11.15 \pm 0.15^{\mathrm{ab}}$ & $0.59 \pm 0.04^{\mathrm{ab}}$ & $63.56 \pm 0.50^{\mathrm{abc}}$ & $16.19 \pm 6.16^{\mathrm{bc}}$ & $627.67 \pm 6.35^{\mathrm{b}}$ \\
\hline $21 \mathrm{~d}$ & $11.70 \pm 0.07^{\mathrm{ab}}$ & $0.68 \pm 0.00^{\mathrm{ab}}$ & $66.70 \pm 0.54^{\mathrm{abc}}$ & $14.40 \pm 0.17^{\mathrm{b}}$ & $770.33 \pm 3.21^{\mathrm{ab}}$ \\
\hline $28 \mathrm{~d}$ & $12.99 \pm 0.02^{b}$ & $0.91 \pm 0.01^{\mathrm{a}}$ & $76.58 \pm 0.63^{\mathrm{bc}}$ & $15.55 \pm 1.17^{\mathrm{bc}}$ & $820.67 \pm 3.79^{\mathrm{abc}}$ \\
\hline $14 \mathrm{~d}$ & $10.09 \pm 0.27^{\mathrm{abd}}$ & $0.51 \pm 0.00^{\mathrm{a}}$ & $49.79 \pm 1.39^{\mathrm{abd}}$ & $10.35 \pm 0.14^{\mathrm{ab}}$ & $427.67 \pm 5.03^{\mathrm{ab}}$ \\
\hline $21 \mathrm{~d}$ & $11.26 \pm 0.08^{\mathrm{abd}}$ & $0.55 \pm 0.01^{\mathrm{a}}$ & $60.67 \pm 0.73^{\mathrm{ab}}$ & $11.40 \pm 0.16^{\mathrm{ab}}$ & $543.33 \pm 18.77^{\mathrm{ab}}$ \\
\hline $28 \mathrm{~d}$ & $12.12 \pm 0.11^{\mathrm{abd}}$ & $0.73 \pm 0.01^{\mathrm{ac}}$ & $67.52 \pm 0.96^{\mathrm{ab}}$ & $13.64 \pm 0.33^{\mathrm{bc}}$ & $723.33 \pm 32.98^{\mathrm{b}}$ \\
\hline \multicolumn{6}{|c|}{$\mathrm{E}\left(1000 \mathrm{mg} / \mathrm{kgbw}\right.$ extract $\left.+\mathrm{CCl}_{4}\right)$} \\
\hline $7 \mathrm{~d}$ & $7.56 \pm 0.02^{\mathrm{ab}}$ & $0.39 \pm 0.00^{\mathrm{ab}}$ & $35.41 \pm 0.03^{\text {abcd }}$ & $7.56 \pm 0.16^{\mathrm{ab}}$ & $304.67 \pm 3.06^{\mathrm{ac}}$ \\
\hline $14 \mathrm{~d}$ & $8.38 \pm 0.05^{\mathrm{ab}}$ & $0.42 \pm 0.00^{\mathrm{ab}}$ & $41.33 \pm 0.99^{\mathrm{abcd}}$ & $8.70 \pm 0.20^{\mathrm{ab}}$ & $367.00 \pm 11.00^{\mathrm{abc}}$ \\
\hline $21 \mathrm{~d}$ & $9.64 \pm 0.16^{\mathrm{abd}}$ & $0.50 \pm 0.00^{\mathrm{ab}}$ & $50.20 \pm 0.05^{\mathrm{abc}}$ & $9.76 \pm 0.38^{\mathrm{ab}}$ & $426.67 \pm 2.89^{\mathrm{abd}}$ \\
\hline $28 \mathrm{~d}$ & $11.49 \pm 0.19^{\mathrm{abc}}$ & $0.65 \pm 0.00^{\mathrm{ab}}$ & $57.51 \pm 2.23^{\mathrm{abd}}$ & $11.17 \pm 4.69^{\mathrm{abc}}$ & $648.00 \pm 43.41^{\mathrm{ab}}$ \\
\hline
\end{tabular}

Values above are means of triplicate determination \pm SD. Values in the same column, bearing the same letters are statistically different $(\mathrm{P}<0.05)$. One way analysis of ANOVA was used in analysing the results.

$\mathrm{a}=$ comparing positive control and other groups

$\mathrm{b}=$ comparing negative control and other groups given extract

$\mathrm{c}=$ comparing groups $\mathrm{C}, \mathrm{D}$ and $\mathrm{E}$

$\mathrm{d}=$ group $\mathrm{D}$ vs group $\mathrm{E}$

Table 7. Serum antioxidant assay of rats administered Sida corymbosa extract after administering carbon tetrachloride.

\begin{tabular}{|c|c|c|c|c|c|}
\hline Groups & GSH (u/ml) & GPx (u/ml) & CAT (u/ml) & SOD $(\mathbf{u} / \mathbf{m l})$ & TAC (u/ml) \\
\hline \multicolumn{6}{|c|}{ A (positive control) } \\
\hline $7 d$ & $13.50 \pm 1.73^{\mathrm{a}}$ & $0.90 \pm 0.06^{\mathrm{a}}$ & $76.72 \pm 2.96^{\mathrm{a}}$ & $16.10 \pm 4.85^{\mathrm{a}}$ & $820.00 \pm 294.70^{\mathrm{a}}$ \\
\hline $14 \mathrm{~d}$ & $13.43 \pm 1.75^{\mathrm{a}}$ & $0.89 \pm 0.06^{\mathrm{a}}$ & $76.70 \pm 3.00^{\mathrm{a}}$ & $15.93 \pm 5.08^{\mathrm{a}}$ & $821.33 \pm 295.47^{\mathrm{a}}$ \\
\hline $21 \mathrm{~d}$ & $13.42 \pm 1.83^{\mathrm{a}}$ & $0.90 \pm 0.05^{\mathrm{a}}$ & $76.69 \pm 2.94^{\mathrm{a}}$ & $16.30 \pm 4.93^{\mathrm{a}}$ & $823.00 \pm 294.78^{a}$ \\
\hline $28 \mathrm{~d}$ & $13.50 \pm 1.73^{\mathrm{a}}$ & $0.90 \pm 0.06^{\mathrm{a}}$ & $76.76 \pm 2.82^{\mathrm{a}}$ & $16.33 \pm 4.93^{\mathrm{a}}$ & $821.67 \pm 294.94^{\mathrm{a}}$ \\
\hline \multicolumn{6}{|c|}{$\mathrm{B}$ (Negative control, rats $+\mathrm{CCl}_{4}$ only) } \\
\hline $7 d$ & $6.21 \pm 0.05^{\mathrm{ab}}$ & $0.35 \pm 0.00^{\mathrm{ab}}$ & $23.23 \pm 4.97^{\mathrm{ab}}$ & $5.01 \pm 0.02^{\mathrm{ab}}$ & $201.33 \pm 13.31^{\mathrm{ab}}$ \\
\hline $21 \mathrm{~d}$ & $6.20 \pm 0.05^{\mathrm{ab}}$ & $0.35 \pm 0.02^{\mathrm{ab}}$ & $29.39 \pm 4.97^{\mathrm{ab}}$ & $5.01 \pm 0.02^{\mathrm{ab}}$ & $202.33 \pm 13.32^{\mathrm{ab}}$ \\
\hline $28 \mathrm{~d}$ & $6.20 \pm 0.05^{\mathrm{ab}}$ & $0.36 \pm 0.01^{\mathrm{ab}}$ & $29.39 \pm 4.94^{\mathrm{ab}}$ & $5.03 \pm 0.02^{\mathrm{ab}}$ & $202.00 \pm 13.86^{\mathrm{ab}}$ \\
\hline \multicolumn{6}{|c|}{$\mathrm{F}\left(5000 \mathrm{mg} / \mathrm{kgbw}\right.$ extract $\left.+\mathrm{CCl}_{4}\right)$} \\
\hline $7 \mathrm{~d}$ & $8.70 \pm 0.37^{\mathrm{ab}}$ & $0.58 \pm 0.09^{\mathrm{abc}}$ & $33.01 \pm 3.06^{\mathrm{abc}}$ & $6.72 \pm 0.02^{\mathrm{ab}}$ & $379.67 \pm 5.51^{\mathrm{abc}}$ \\
\hline $14 \mathrm{~d}$ & $8.85 \pm 0.29^{\mathrm{ab}}$ & $0.73 \pm 0.08^{\text {abcd }}$ & $54.22 \pm 10.82^{\mathrm{ab}}$ & $6.92 \pm 0.13^{\mathrm{abc}}$ & $363.00 \pm 39.23^{\mathrm{abc}}$ \\
\hline $21 \mathrm{~d}$ & $8.80 \pm 0.0 .07^{\mathrm{ab}}$ & $0.73 \pm 0.03^{\mathrm{abcd}}$ & $65.03 \pm 3.00$ & $11.70 \pm 0.01^{\mathrm{abc}}$ & $597.33 \pm 80.75$ \\
\hline $28 \mathrm{~d}$ & $9.87 \pm 0.19^{\mathrm{b}}$ & $0.87 \pm 0.09^{\text {bcd }}$ & $70.84 \pm 1.19^{\mathrm{b}}$ & $16.71 \pm 0.02^{\mathrm{bc}}$ & $655.67 \pm 58.86^{\mathrm{bc}}$ \\
\hline
\end{tabular}




\begin{tabular}{|c|c|c|c|c|c|}
\hline Groups & GSH (u/ml) & GPx (u/ml) & CAT (u/ml) & SOD $(\mathrm{u} / \mathrm{ml})$ & TAC (u/ml) \\
\hline $14 \mathrm{~d}$ & $8.92 \pm 0.42^{\mathrm{ab}}$ & $0.59 \pm 0.05^{\text {abcd }}$ & $46.75 \pm 3.02^{\mathrm{ab}}$ & $7.08 \pm 0.46^{\mathrm{ab}}$ & $418.67 \pm 75.63^{\mathrm{ab}}$ \\
\hline $21 \mathrm{~d}$ & $9.25 \pm 0.64^{\mathrm{ab}}$ & $0.61 \pm 0.03^{\mathrm{abcd}}$ & $61.35 \pm 6.22^{\mathrm{ab}}$ & $9.61 \pm 0.01^{\mathrm{b}}$ & $545.67 \pm 3.21^{\mathrm{abc}}$ \\
\hline $28 \mathrm{~d}$ & $9.48 \pm 0.18^{\mathrm{ab}}$ & $0.74 \pm 0.00^{\mathrm{bcd}}$ & $67.94 \pm 0.01^{\mathrm{ab}}$ & $11.67 \pm 3.25^{\mathrm{bcd}}$ & $557.67 \pm 7.51^{\mathrm{ab}}$ \\
\hline \multicolumn{6}{|c|}{$\mathrm{H}\left(1000 \mathrm{mg} / \mathrm{kgbw}\right.$ extract $\left.+\mathrm{CCl}_{4}\right)$} \\
\hline $7 \mathrm{~d}$ & $7.48 \pm 0.35^{\mathrm{ab}}$ & $0.51 \pm 0.00^{\mathrm{ab}}$ & $28.60 \pm 8.52^{\mathrm{a}}$ & $5.60 \pm 0.01^{\mathrm{a}}$ & $249.67 \pm 22.37^{\mathrm{a}}$ \\
\hline $14 \mathrm{~d}$ & $8.11 \pm 0.13^{\mathrm{ab}}$ & $0.61 \pm 0.05^{\mathrm{ab}}$ & $44.71 \pm 2.72^{\mathrm{abcd}}$ & $6.25 \pm 0.44^{\mathrm{ab}}$ & $283.67 \pm 5.51^{\mathrm{ab}}$ \\
\hline $21 \mathrm{~d}$ & $8.94 \pm 0.01^{\mathrm{ab}}$ & $0.67 \pm 0.01^{\mathrm{abd}}$ & $49.55 \pm 0.98^{\mathrm{abc}}$ & $7.61 \pm 0.10^{\mathrm{ab}}$ & $519.67 \pm 13.80^{\mathrm{ab}}$ \\
\hline $28 \mathrm{~d}$ & $9.16 \pm 0.15^{\mathrm{ab}}$ & $0.63 \pm 0.05^{\text {abd }}$ & $53.53 \pm 150^{\mathrm{abc}}$ & $10.21 \pm 0.18^{\mathrm{ab}}$ & $542.33 \pm 4.04^{\mathrm{ab}}$ \\
\hline
\end{tabular}

Values above are means of triplicate determination $\pm \mathrm{SD}$. Values in the same column, bearing the same letters are statistically different $(\mathrm{P}<0.05)$. One way analysis of ANOVA was used in analysing the results.

$\mathrm{a}=$ comparing positive control and other groups

$\mathrm{b}=$ comparing negative control and other groups given extract

$\mathrm{c}=$ comparing groups $\mathrm{C}, \mathrm{D}$ and $\mathrm{E}$

$\mathrm{d}=$ group $\mathrm{D}$ vs group $\mathrm{E}$

The results of serum malondialdehyde (MDA) assay of rats administered carbon tetrachloride before and after administering Sida corymbosa ethanolic leaf extract are hereby presented on tables 8-9. Serum MDA levels were significantly higher $(\mathrm{P}<0.05)$ in rats administered $\mathrm{CCl}_{4}$ only (negative control) than in rats in positive control groups, rats administered 5000, 3000 and $1000 \mathrm{mg} / \mathrm{kgbw}$ of the extract before and after $\mathrm{CCl}_{4}$ administration (groups A-H) Malondialdehyde (MDA) level was higher significantly in rats administered $1000 \mathrm{mg} / \mathrm{kgbw}$ and $3000 \mathrm{mg} / \mathrm{kgbw}$ than in rats administered $5,000 \mathrm{mg} / \mathrm{kgbw}$ from $7-28 \mathrm{~d}$, for both rats administered the extract before and after $\mathrm{CCl}_{4}$ administration.

Table 8. Serum malondialdehyde level of rats administered Sida corymbosa extract before administering.

\begin{tabular}{ll}
\hline Carbon tetrachloride & MDA (nmol/ml) \\
\hline Groups & $1.06 \pm 0.15^{\mathrm{a}}$ \\
\hline A (positive control) & $1.07 \pm 0.01^{\mathrm{a}}$ \\
$7 \mathrm{~d}$ & $1.06 \pm 0.17^{\mathrm{a}}$ \\
$14 \mathrm{~d}$ & $1.06 \pm 0.02^{\mathrm{a}}$ \\
$21 \mathrm{~d}$ & \\
$28 \mathrm{~d}$ & $2.08 \pm 0.51^{\mathrm{ab}}$ \\
B (Negative control, rats $+\mathrm{CCl}_{4}$ only) & $2.42 \pm 0.23^{\mathrm{ab}}$ \\
$7 \mathrm{~d}$ & $3.42 \pm 0.23^{\mathrm{ab}}$ \\
$14 \mathrm{~d}$ & $4.08 \pm 0.50^{\mathrm{ab}}$ \\
$21 \mathrm{~d}$ & \\
$28 \mathrm{~d}$ & $1.18 \pm 0.01^{\mathrm{bc}}$ \\
$\mathrm{F}\left(5000 \mathrm{mg} / \mathrm{kgbw}\right.$ extract $\left.+\mathrm{CCl}_{4}\right)$ & $1.15 \pm 0.01^{\mathrm{bc}}$ \\
$7 \mathrm{~d}$ & $1.12 \pm 0.01^{\mathrm{bc}}$ \\
$14 \mathrm{~d}$ & $1.07 \pm 0.02^{\mathrm{bc}}$ \\
$21 \mathrm{~d}$ & \\
$28 \mathrm{~d}$ & $1.25 \pm 0.01^{\mathrm{bd}}$ \\
$\mathrm{G}\left(3000 \mathrm{mg} / \mathrm{kgbw}\right.$ extract $\left.+\mathrm{CCl}_{4}\right)$ & $1.17 \pm 0.01^{\mathrm{bd}}$ \\
$7 \mathrm{~d}$ & $1.14 \pm 0.01^{\mathrm{bd}}$ \\
$14 \mathrm{~d}$ & $1.12 \pm 0.01^{\mathrm{bd}}$ \\
$21 \mathrm{~d}$ & \\
$28 \mathrm{~d}$ & $2.02 \pm 0.0 .01^{\mathrm{abcd}}$ \\
$\mathrm{H}\left(1000 \mathrm{mg} / \mathrm{kgbw}\right.$ extract $\left.+\mathrm{CCl}_{4}\right)$ & $1.47 \pm 0.0 .08^{\mathrm{abc}}$ \\
$7 \mathrm{~d}$ & $1.20 \pm 0.01^{\mathrm{b}}$ \\
$14 \mathrm{~d}$ & $1.16 \pm 0.01^{\mathrm{ab}}$ \\
$21 \mathrm{~d}$ & 1 \\
\hline
\end{tabular}

Values above are means of triplicate determination $\pm \mathrm{SD}$. Values in the same column, bearing the same letters are statistically different $(\mathrm{P}<0.05)$. One way analysis of ANOVA was used in analysing the results.

$\mathrm{a}=$ comparing positive control and other groups

$\mathrm{b}=$ comparing negative control and other groups given extract

$\mathrm{c}=$ comparing groups $\mathrm{C}, \mathrm{D}$ and $\mathrm{E}$

$\mathrm{d}=$ group D vs group $\mathrm{E}$

Table 9. Serum malondialdehyde level of rats administered Sida corymbosa extract before administering Carbon tetrachloride.

\begin{tabular}{ll}
\hline Groups & MDA (nmol/ml) \\
\hline A (positive control) & \\
$7 \mathrm{~d}$ & $1.06 \pm 0.15^{\mathrm{a}}$ \\
$14 \mathrm{~d}$ & $1.07 \pm 0.01^{\mathrm{a}}$ \\
$21 \mathrm{~d}$ & $1.06 \pm 0.17^{\mathrm{a}}$ \\
\hline
\end{tabular}




\begin{tabular}{ll}
\hline Groups & MDA (nmol/ml) \\
\hline $28 \mathrm{~d}$ & $1.06 \pm 0.02^{\mathrm{a}}$ \\
B (Negative control, rats $+\mathrm{CCl}_{4}$ only) & $2.08 \pm 0.51^{\mathrm{ab}}$ \\
$7 \mathrm{~d}$ & $2.42 \pm 0.23^{\mathrm{ab}}$ \\
$14 \mathrm{~d}$ & $3.42 \pm 0.23^{\mathrm{ab}}$ \\
$21 \mathrm{~d}$ & $4.08 \pm 0.50^{\mathrm{ab}}$ \\
$28 \mathrm{~d}$ & \\
$\mathrm{~F}\left(5000 \mathrm{mg} / \mathrm{kgbw}\right.$ extract $\left.+\mathrm{CCl}_{4}\right)$ & $1.18 \pm 0.01^{\mathrm{bc}}$ \\
$7 \mathrm{~d}$ & $1.16 \pm 0.01^{\mathrm{bc}}$ \\
$14 \mathrm{~d}$ & $1.14 \pm 0.01^{\mathrm{bc}}$ \\
$21 \mathrm{~d}$ & $1.08 \pm 0.02^{\mathrm{bc}}$ \\
$28 \mathrm{~d}$ & \\
$\mathrm{G}\left(3000 \mathrm{mg} / \mathrm{kgbw}\right.$ extract $\left.+\mathrm{CCl}_{4}\right)$ & $1.31 \pm 0.06^{\mathrm{bcd}}$ \\
$7 \mathrm{~d}$ & $1.21 \pm 0.01^{\mathrm{bcd}}$ \\
$14 \mathrm{~d}$ & $1.46 \pm 0.47^{\mathrm{bcd}}$ \\
$21 \mathrm{~d}$ & $1.16 \pm 0.15^{\mathrm{bcd}}$ \\
$28 \mathrm{~d}$ & \\
$\mathrm{H}\left(1000 \mathrm{mg} / \mathrm{kgbw}\right.$ extract $\left.+\mathrm{CCl}_{4}\right)$ & $2.12 \pm 0.0 .01^{\mathrm{abcd}}$ \\
$7 \mathrm{~d}$ & $1.92 \pm 0.08^{\mathrm{bcd}}$ \\
$14 \mathrm{~d}$ & $1.68 \pm 0.03^{\mathrm{bcd}}$ \\
$21 \mathrm{~d}$ & $1.42 \pm 0.09^{\mathrm{bcd}}$ \\
$28 \mathrm{~d}$ & \\
\hline
\end{tabular}

Values above are means of triplicate determination $\pm \mathrm{SD}$. Values in the same column, bearing the same letters are statistically different $(\mathrm{P}<0.05)$. One way analysis of ANOVA was used in analysing the results.

$\mathrm{a}=$ comparing positive control and other groups

$\mathrm{b}=$ comparing negative control and other groups given extract

$\mathrm{c}=$ comparing groups $\mathrm{C}, \mathrm{D}$ and $\mathrm{E}$

$\mathrm{d}=$ group $\mathrm{D}$ vs group $\mathrm{E}$

\section{Discussion}

Antioxidant drugs have been known to be used in managing oxidative stress. The rate of use of antioxidant drugs have increased alarmingly due to increased exposure to xenobiotic substances such as carbon tetrachloride [2]. Recently, in many parts of the world, people are beginning to show more interest in the used of herbs as natural antioxidant supplements in the management of oxidative stress.

This study investigated the antioxidant effects of Sida corymbosa ethanolic leaf extracts on Albino-male Wistar rats before and after carbon tetrachloride administration from 7 $\mathrm{d}-28 \mathrm{~d}$ of treatment.

In vitro antioxidants of plants have been used as a means of investigating the potentials of plants for protecting free radical-induced organ or tissue damage in various experimental models. A lot of metabolic processes such as UV radiation, stress, etc. cause the generation of free radicals. The increased generation of free radicals or depletion of dietary antioxidant causes pro-oxidant to dominate [4]. A lot of plants contain a lot of antioxidant molecules and enzymes to content with this problem.

The in vitro antioxidant assay carried out showed that the inhibition of all the extracts (aqueous and ethanolic root and leaf ) and the respective standards against free radicals for DPPH, FRAP, iron chelating and hydroxyl radical assay increased as the concentration of the extracts and standards increased from $31.25 \mathrm{mg} / \mathrm{ml}$ to $1000 \mathrm{mg} / \mathrm{ml}$. This suggests that the extracts may have potency against DPPH radicals, $\mathrm{Fe}^{3+}$, $\mathrm{FeCl}_{3}$ and hydroxyl free radicals which may be dependent on concentration. Similar reports have been made by Maduka et al., [12], on "in vitro free radical scavenging and antioxidant activities of aqueous extracts of Crateva adansonii (Three-leaf Plant)", Maduka et al., [33]. The higher antioxidant activities exhibited by ethanolic and aqueous leaf extracts than EDTA, trolex and quercetin standards for chelating iron effect, FRAP and hydroxyl radicals shows that ethanolic and aqueous leaf extracts of this plant are potent antioxidants against $\mathrm{Fe}^{2+}$, ferric chloride and hydroxyl free radicals. This is in line with the smilar reports of Kalita et al., [24], on "Estimation of total flavonoids content and antioxidant activities of methanolic whole plant extract of Biophytum sensitivum Linn", Maduka et al., [12], on the in vitro antioxidant activities of leaf extracts of Crativa adansonii, Shwetha and Sudha, [23], on "in vitro free radical scavenging activity of aqueous extract from the Mycelia of Volvariella volvacea (Bulliard Ex Fries)".

The in vitro antioxidant activities shown in this work by Sida corymbosa extracts could be as a result of the antioxidant content of the extracts as identified during phytochemical analysis reported by Dike et al., [3]. Antioxidant activities against DPPH and ferric chloride radicals were observed to be more prominent in ethanolic leaf extract than other extracts. This may also be suggesting that ethanolic leaf extract of this plant may have more antioxidant activities against DPPH radicals than the root when using ethanol as extractor. This agrees with the similar report of Shwetha and Sudha, [23]. Ethanol and aqueous root extracts exhibited significant low antioxidant activities under FRAP assay. This could mean that ethanolic and aqueous root extracts of this plant may have weak antioxidant activities against ferric chloride free radicals. This is supported by similar finding of Palaksha et al., [4], on "Comparative in vitro antioxidant activity on Melochia corchorifolia, Sida acuta and Saccharum officinarum leaf 
extracts and their phenolic contents". The total antioxidant assay also revealed that ethanolic leaf extract of Sida corymbosa had higher total antioxidant capacity than other extracts (aqueous leaf, ethanolic root and aqueous root extracts of Sida corymbosa).

Oral toxicity $\left(\mathrm{LD}_{50}\right)$ test of a drug or substance intended to be used as a drug which is that dose than can kills $50 \%$ of the animal is a basic toxicity test carried out using a model animal to determine the toxic level of that drug [13, 14]. The oral acute toxicity $\left(\mathrm{LD}_{50}\right)$ study of Sida corymbosa ethanolic leaf extract was therefore carried out which showed that Sida corymbosa ethanolic leaf extract's $\mathrm{LD}_{50}$ was above 5000 $\mathrm{mg} / \mathrm{kgbw}$. This may be suggesting that the extract may be non-toxic and safe since the $\mathrm{LD}_{50}$ falls within the dose range for non-toxic chemicals. According to Organization for Economic Cooperation Development (OECD), (1995), the recommended dose range for non-toxic and safe chemicals is between 5,000-15,000 mg/kgbw. This agrees with the findings of Lucy and Mercy, [19] and Lucy et al., [22].

The second phase of this work was carried out based on the outcome of oral toxicity test of ethanolic leaf extract of Sida corymbosa, by investigating the antioxidant effects of Sida corymbosa ethanolic leaf extract before and after administering carbon tetrachloride on rats. Sida corymbosa ethanolic leaf extract was chosen to be used on the rats because in vitro antioxidant assays done so far suggest that the extract had more in vitro antioxidant activities than the other extracts. This was done using $5000 \mathrm{mg} / \mathrm{kgbw}, 3000 \mathrm{mg} / \mathrm{kgbw}$ and $1000 \mathrm{mg} / \mathrm{kgbw}$ of the extract.

Antioxidants are those molecules which neutralize pro-oxidants (reactive species), thereby destroying them. Antioxidants are synthesized through several mechanisms, naturally or gotten externally from food substances [8]. The antioxidants substances such as vitamin $\mathrm{C}$, tannin, rutin, kaempferol, epicatechin and catechin come from food substances such as fruits, vegetables, spices, grains, grape and green tea. Molecules such as uric acid, vitamin $\mathrm{C}$ and glutathione play major roles as the antioxidants of cells ${ }^{7}$. Antioxidants in human body are known to be produced in response to damages induced by oxidative stress to molecules and altering their regular functions. These molecules include DNA, protein and lipids. Serum antioxidants prevent autoxidation of macromolecules such as DNA, proteins and lipids, thereby protecting the liver from damage by reactive species [4]. The serum antioxidant status of the Albino rats evaluated revealed that for both the groups given Sida corymbosa ethanolic leaf extract before and after $\mathrm{CCl}_{4}$ injection, levels of serum reduced glutathione (GSH), catalase (CAT), supraoxide dismutase (SOD) and total antioxidant capacity (TAC) increased significantly throughout the treatment period. The greatest changes in the above parameters were witnessed in groups given $5000 \mathrm{mg} / \mathrm{kgbw}$ of the extract, followed by those given $3000 \mathrm{mg} / \mathrm{kgbw}$ from 7 days to 28 days of treatment. These suggest that Sida corymbosa ethanolic leaf extract may have improved antioxidant levels of rats before and after $\mathrm{CCl}_{4}$ administration in a dose and time dependent manner. Similar findings had been made by Maher et al., [9].

According to Obi et al., [7], oxidative stress occurs when there is imbalance between oxidants and antioxidants levels in the body. An increase in oxidants will leads to decrease in antioxidant status characterized by increased level of serum malondialdehyde and decreased levels of antioxidants molecules such as SOD, GSH, GPx, CAT and TAC. When lipid peroxidation occurs, MDA is released as a bye product which reacts with 2-thiobarbituric acid (TBA) to form a pink-coloured compound [7]. This is one of the measures being used to access oxidative stress in human body. The results of this findings revealed that MDA levels increased in negative control group (untreated group) of rats and decreased significantly in groups administered Sida corymbosa ethanolic extract before and after $\mathrm{CCl}_{4}$ administration. The increase in MDA levels in negative control group of rats may be as a result of lipid peroxidation induced by $\mathrm{CCl}_{4}$ while the decreased of MDA levels in groups of rats administered Sida corymbosa ethanolic leaf extract before and after $\mathrm{CCl}_{4}$ administration may be suggesting that the treatment with the extract may have reversed oxidative stress in groups administered the extract after administering $\mathrm{CCl}_{4}$ and many have prevented oxidative to some extent in groups administered the extract before administering $\mathrm{CCl}_{4}$. These findings were in agreement with the findings of Palaksha et al., [4] and Obi et al., [7]. Many medicinal plants have been reported to have dosage effects on the treatment of liver oxidative stress $[2,9,10]$.

\section{Conclusion}

The findings in this work have so far revealed that Sida corymbosa ethanolic leaf extract may have positive effects on antioxidant status of rats administered carbon tetrachloride. This may be dependent on dose with $5,000 \mathrm{mg} / \mathrm{kgbw}$ of the extract being the best dose, followed by $3,000 \mathrm{mg} / \mathrm{kgbw}$. This extract may therefore, be a good natural antioxidant supplement.

\section{Recommendations and Further Studies}

The study carried out is just preclinical study. I am, therefore, recommending that proper epidemiological studies be carried out on this work before extrapolating the findings of this work to humans. A comprehensive clinical, quality and safety assurance studies need to be carried out on the use of Sida corymbosa extracts for its use in modern day medicine and commercial exploitation as it may be a good drug target for pharmaceutical industries.

Studies should be directed towards the effects of the extract on DNA oxidative damage induced by $\mathrm{CCl}_{4}$ and to know whether the extract has any side effects on blood and weights of Albino Wistar rats.

\section{Conflict of Interest}

Authors declare that there was no conflict of interest. 


\section{References}

[1] Dike C. C., F. C. Ezeonu, H. C. C. Maduka, E. N. Ezeokafor and C. E. Oguazu (2018a). Hepatoprotective potentials of Sida corymbosa ethanolic leaf extract against carbon tetrachloride-induced hepatotoxicity on male Albino Wistar rats. Journal of Pharmacognosy and Phytochemistry 7, 1266-1275.

[2] Dike C. C., F. C. Ezeonu, H. C. C. Maduka, E. N. Ezeokafor and C. E. Oguazu (2018b). Hepatotherapeutic potentials of Sida corymbosa (Wire weed) ethanolic leaf extract against carbon tetrachloride $\left(\mathrm{CCl}_{4}\right)$-induced acute hepatotoxicity in male Albino rats. European Journal of Pharmaceutical and Medical Research 5, 146-155.

[3] Dike C. C., F. C. Ezeonu, H. C. C. Maduka, E. N. Ezeokafor (2018c). Phytochemical and elemental analysis of Sida corymbosa leaf and root extracts. International Journal of Chemical Sciences 24, 1-9.

[4] Palaksha M. N., K. Ravishankar and S. V. Girija (2016). Comparative in vitro antioxidant activity on Melochia corchorifolia, Sida acuta and Saccharum officinarum leaf extracts and their phenolic contents. Saudi Journal of Medical and Pharmaceutical Sciences 2, 198-204.

[5] Maduka H. C. C., C. E. Ugwu, C. C. Dike, A. N. Okpogba, P. N. Ogueche, M. S. Ali and SS. Bakare (2017b). Tino J. In vitro free radical scavenging and antioxidant activities of aqueous extracts of Cateva adansonii (Three leaf plant). Journal of Advances in Medical and Pharmaceutical Sciences 15, 1-8.

[6] Jian-Ming L. O., H. L. Peter, Y. Qizhi and C (2010). Changyi Chemical and molecular Mechanisms of antioxidants: experimental approaches and model systems. Journal of Cell and Molecular Medicine 14, 840-860.

[7] Obi U. L., A. Norah, C. Okafor, C. E. Dioka and S. C. Meludu (2017). Evaluation of total antioxidant status, supraoxide dismutase and malondialdehyde in apparently healthy active tobacco smokers in Nnewi Metropolis, South-East, Nigeria Journal of Scientific Innovation and Research 6, 105-112.

[8] Maduka H. C. C., A. N. Okpogba, C. E, Ugwu, C. C. Dike P. N Ogueche, D. T, Onwuzuruike and D. C. Ibe (2015). Phytochemical, antioxidant and microbial inhibitory effects of Spondias mombin leaf and stem bark extracts. Journal of Pharmaceutical and Biological Sciences 9, 14-17.

[9] Maher A. A., A. E. Mohamed and A Aya (2015). The role of Ficus carica leaf extract in modulation of the experimentally-induced hepatotoxicity damage in male rats. International Journal of Advanced Research 3, 572-588.

[10] Kebe E. O., U. Gabriel C. Kelechi and O. I (2015). Anozeng The effect of Sida acuta on glycogen profile of adult Wistar rat. Global Journal of Biology, Agriculture and Health Sciences 4, 52-55.

[11] Philip N. N., E. Guillaume D. E. and V. Peter (2018). Antony Contrasting nickel and zinc hyperaccumulation in subspecies of Dichapetalum gelonioides from Southeast Asia. Scientific Reports 8, 9659.

[12] Maduka H. C. C., E. I. Akubugwo, O. Olorunipe, A. N. Okpogba, A. A. Maduka, C. U. Ayuru, C. E. Ugwu, C. C. Dike and P. N. Ogueche (2016). Elemental composition and phytochemical screening of aqueous leaf extract and stem bark extract of Crateva adansonii. International Journal of Biochemistry Research and Review 10, 1-7.
[13] Adepoju A A., I. Desalu, W. L. Adeyemo and M. O. Akintimoye (2011). Airway and respiratory complications in children undergoing cleft lip and palate repair. Ghana Medical Journal 10, 44: 1-10.

[14] Mehran R., V. R. Sunil, L. Deepak, C. Michael, C. Adriano and E. John (2010). Standardized bleeding, definitions for cardiovascular clinical trials: a consensus report from the bleeding academic research consortium. Circulation 123, 2736-2747.

[15] Biswanath D., D. Niranjan, D. Subhajit, D. Manikarna, and S. Indrajit (2012). The genus Sida L.-traditional medicine: Its ethnopharmacological, phytochemical and pharmacological data for commercial exploitation in herbal drugs industry. J Ethnopharmacology 15, 135-176.

[16] Ajithabai MD., SP. Sunitha, S. Balachandran and G. Jayakumar (2015). The use of Sida plant in the preparation of Nayapayam kashayam. International Journal of Research and Applied Sciences 3, 99-102.

[17] Sundarganapath R., V. Niraimathi, T. Ananda, M. Jambulingm, B. Narasimhan and D. Aakash (2013). Phytochemical studies and pharmacological screening of Sida rhombifalia Linn. Hygeia. Journal of Dental Medicine 5, 19-22.

[18] Lucy BJ., and A. Mercy (2015). Evaluation of the haemostatic activities of Sida corymbosa in rats. British Journal of Pharmaceutical Research 5, 431- 436.

[19] Mahesh T., M. Shashank, R. S. Kalidhindi, S. P Dhanabai and D. N. Ashish (2016). In vitro and in vivio evaluation of Sida acuta burm. f. (Malvaceae) for its antioxidant and anticancer activity. Der Pharmachemical 8, 396-402.

[20] Abat J., S. Kumar and A. Mohanty (2017). Ethnomedicinal, phytochemical and ethnopharmacological aspects of four medicinal plants of malvaceae used in Indian traditional Medicine: A review. Medicines 75, 1-8.

[21] Lucy J., Y. and Y. I. Tijani (2014). Christianah Anti-ulcer and wound healing activities of Sida corymbosa in rats. African Journal of Traditional, Complementary and Alternative Medicine 11, 87-92.

[22] Shwetha K. and G. M. Sudha (2012). In vitro free radical scavenging activity of aqueous extract from the mycelia of Volvariella volvacea (Bulliard Ex Fries) Singer. International Journal of Current Pharmaceutical Research 4, 94-100.

[23] Kalita P., T. K. Barman, T. K. Pal and R. Kalita (2013). Estimation of total flavonoids content (TFC) and antioxidant activities of methanolic whole plant extract of Biophytum sensitivum Linn. Journal of Drug Delivery and Therapeutics 3, 33-37.

[24] Aliyu R., Z. S. C. Okoye and W. T. Shier (2012). The hepatoproctective cytochrome P-450 enzyme inhibitor isolated from Nigerian medicinal plant Cochlospermum planchonii is a zinc salt. Journal of Ethnopharmacology 48, 89-97.

[25] Enegide C., A. David and S. A. (2013). Fidelis A new Method for determining acute toxicity in animal models. Toxicology International. 20: 224-226.

[26] WHO (2004). Recommendations for the preparation, characterization and establishment of International and other biological reference stardards. WHO Experimental Committee on biological standardization. Fifty-fifth report. WHO Technical Report Series No 932. http://www.whoint/blood products/norms/en/(accessed 13 July 2004). 
[27] Beutiler E. (1993). Enzyme replacement therapy for Gaucher's disease. Baillieres Clinical Haematology 10, 751-763.

[28] Hadwan M. H and H. N. (2016). Abed Data supporting the estimation of catalase activity. Data Brief. 6: 194-199.

[29] Rotruck J. T, A. L. Pope, H. E. Ganther, A. B. Swanson, D. G. Hafeman and J. H. William (1993). Selenium Biochemical Role as a component of glutathione peroxidase. Science 179, 588-590.

[30] Benzie I. F. F. and J. J. Strain [1996]. The ferric reducing ability of plasma (FRAP) as a measure of antioxidant power. The FRAP assay. Analytical Biochemistry 239, 70- 76.

[31] Alam Z. and U. C. Fareed (2016). A simple spectrophotometric method for the determination of thiobarbitutric acid reactive substance in fried fast foods. Journal of Analytical Methods in Chemistry 8, 1-5.

[32] Maduka H. C. C., A. A. Maduka, C. U. Aguoru, A. Myke-Mbata, J. O. Ikwue, A. N. Okpogba, Ugwu C. E, C. C. Dike, P. N. Ogueche, D. O. Ochalefu, U. Nath, J. Yakubu and E. Shatu (2017a). Phytochemical screening, spectrophotometric determination of total carotenoids, chlorophyll a and b components of Crateva adansonii (Three-leaf Plant). Journal of Advanced Medical and Pharmaceutical Sciences 15, 1-6.

[33] Perumalsamy M., D. Subburaj, C. P. Palanisamy, K. G. Velliyur and Kannappan (2016). Phytochemical Screening and free radical scavenging activity of chloroform extract of Sida acuta Burn F. International Journal of Pharmacognosy and phytochemical Research 8, 663-667. 